\title{
Nanoteknoloji ve Nanobiyomalzemeler: Ă̆ız Kanserini Yönetme Yollarını Yeniden Tanımlama
}

\section{Nanotechnology and Nanobiomaterials: Redefining Ways of Managing Oral Cancer}

\author{
${ }^{1}$ Akanksha JUNEJA, ${ }^{1}$ Amina SULTAN \\ Akanksha Juneja: https://orcid.org/0000-0003-4127-1133 \\ Amina Sultan: https://orcid.org/0000-0001-5245-4416
}

${ }^{1}$ Dept of Pediatric and Preventive Dentistry, Faculty of Dentistry, Jamia Millia Islamia, New Delhi

\section{ÖZ}

Nano-biyoteknoloji, biyolojik alanda çeşitli nanoteknolojilerin uygulaması olarak düşünülebilir. Nano parçacıkların ortaya çıkmasıyla, bilim camiasında bir devrim gerçekleşti. Nanoteknoloji ve tıbbın yakınlaşması, son zamanlarda disiplinler arası bir alana, yani nanotıpa yol açtı; bu, algılama, görüntüleme ve ilaç dağıtım cihazlarını iyileştirmeye çalışan mühendisleri, fizikçileri, biyologları, kimyagerleri, matematikçileri ve doktorları bir araya getirdi. Kanser, dünyadaki ölümlerin önde gelen nedenidir. Tükürük bezleri, tiroid, ağız boşluğu, yutak, nazofarenks ve gırtlak dahil olmak üzere baş ve boyun kanserleri, dünyadaki kanser vakalarının yüksek yüzdesini oluşturur. Şu anda mevcut tedavi modaliteleri çok sınırlıdır. Kanser yönetimi için nano-biyoteknolojileri kullanmanın yollarını bulmak için biyofizik uzmanları, moleküler biyologlar ve tıp pratisyenlerinin işbirliğini içeren multidisipliner bir yaklaşıma ihtiyaç vardır. Bu nedenle bir tedavi bulmak için nano biyomalzeme ve tıbbın bir araya gelebileceği yeni stratejiler tasarlamaya odaklanılması gerekiyor.

Anahtar Kelimeler: Maligniteler, nano-biyoteknoloji, nano partiküller, oral skuamöz hücreli karsinom

\begin{abstract}
Nano-biotechnology can be considered as application of various nanotechnologies in the biological field. With the advent of nano-particles, a revolution has come in the scientific community. The convergence of nanotechnology and medicine recently led to an interdisciplinary field, nanomedicine, which brings together engineers, physicists, biologists, chemists, mathematicians, and physicians striving to improve detection, imaging, and drug-delivery devices. Cancer is a leading cause of mortality in the world. Cancers of the head and neck-including the salivary glands, thyroid, oral cavity, pharynx, nasopharynx, and larynxaccount for the high percentage of malignancies of the world. At present the treatment modalities available are very limited. A multidisciplinary approach is needed, including the cooperation of biophysics experts, molecular biologists and medical practitioners, to find ways of using nano-biotechnologies for cancer management. Hence focus focus needs to be shifted to designing new strategies where nano-biomaterials and medicine can come together to find a cure.
\end{abstract}

Keywords: Malignancies, nano-biotechnology, nano particles, oral squamous cell carcinoma
Sorumlu Yazar / Corresponding Author:

Akanksha Juneja

Associate Professor, Dept Of Pediatric and Preventive Dentistry,

Faculty of Dentistry, Jamia Millia Islamia, New Delhi

Phone: 9971404330

Email: ajuneja@jmi.ac.in

Atıf/ Cited: Juneja A and Sultan A. Nanotechnology and Nanobiomaterials: Redefining Ways of Managing Oral Cancer. Online Türk Sağllk Bilimleri Dergisi 2020;5(4):693-700. doi: 10.26453/otjhs.753846

\section{Yayın Bilgisi / Article Info:}

Gönderi Tarihi/ Received: 16/06/2020

Kabul Tarihi/ Accepted: 22/09/2020

Online Yayın Tarihi/ Published: 30/12/2020

\section{INTRODUCTION}

Nano-biotechnology can be considered as application of various nanotechnologies in the biological field. Various scientific fields like, chemistry, physics, molecular biology, engineering converge to formulate nano-biotechnology. With the advent of nano-particles, a revolution has come in the scientific community. It is interesting to note that these particles in nano form demonstrate multiple physical properties like electronic, magnetic, optical etc. which are absent in their usual form. Through ap- propriate size and chemical properties matching, these particles can be used in conjunction with biologically active molecules; thereby widening their range of application in biology and medicine. ${ }^{1,2}$

Cancer is a leading cause of mortality in the world. Cancers of the head and neck-including the salivary glands, thyroid, and the mucosal lining of the oral cavity, pharynx, nasopharynx, and larynxaccount for the high percentage of malignancies of the world. The treatment modalities available today for treatment of oral and maxillofacial cancer are 
chemotherapy, radiation therapy, surgery and antibody blocking therapy or a combination of these. In spite of these advances, there is only a little improvement in the survival rate in such cases. ${ }^{3,4}$

Oral squamous cell carcinoma (OSCC) represents an excellent model for both head and neck cancer and solid malignancies in general. It is the sixth most common cancer for both sexes worldwide. Most of the time it is diagnosed at an advanced or an untreatable stage; where carcinoma cells have become aggressive and resistant to therapeutic drugs. ${ }^{5}$ Nearly $85 \%$ of all malignancies are of epithelial origin including the skin, oral cavity, nasopharyngeal, laryngeal, lung, gastrointestinal, colon, and bladder cancer. Oral cancer is an aggressive malignancy that invades local tissue, spreads to regional and distant sites, and has an overall 5-year survival of $60 \%{ }^{6}$ About $80 \%$ to $90 \%$ of OSCC overexpress a surface antigen important to tumour growth and proliferation known as epithelial growth factor receptor (EGFR). ${ }^{7}$ Analogous surface receptors exist on other solid tumours, making EGFR an excellent model for investigation of antibody-based targeting of tumours. Antibody-blocking therapy in combination with radiation therapy has been successful in reducing the associated toxicity for the patient. ${ }^{4}$ Detecting oral cancer at its earliest is thus vital for improving the survival rate of this disease. Current clinical diagnosis of most epithelial cancers, including oral cancer, typically involves performing invasive needle biopsies followed by histological examination on the excised tissue. The procedure may present psychological trauma and risk of infection to patients. Furthermore, a biopsy is usually performed only under the condition that the lesions are spotted and appear abnormal. ${ }^{8}$ Yet, pre-cancerous lesions can appear innocuous or occur in hidden sites such as the crypts in the base of the tongue, and can therefore easily go undetected even with white-light endoscopy. ${ }^{5}$ Furthermore, conventional histopathological diagnosis is based on morphological and structural changes at the cellular or tissue level, which may not be obvious for early-stage tumours. ${ }^{9}$ Taken together, it is clear that a diagnostic method for detecting early-stage oral cancer is highly desired. Recently, increased amount of efforts have been made to develop less-invasive early diagnostic modalities for oral cancer, of one of them is

which the in vivo high-resolution imaging of oral epithelial tissues using novel optical systems. ${ }^{10}$ Nanotechnology and nanobiomaterials can open new roads for diagnosis as well as targeted treatment of oral cancer.

\section{NANOTECHNOLOGY AND MEDICINE}

The convergence of nanotechnology and medicine recently led to an interdisciplinary field, nanomedicine, which brings together engineers, physicists, biologists, chemists, mathematicians, and physicians striving to improve detection, imaging, and drugdelivery devices. Nanomedicine is a subfield of nanotechnology. It is often defined as the repair, construction, and control of human biological systems using devices built upon nanotechnology standards. Nanomedicine is the medical application of nanotechnology. The approaches to nanomedicine range from the medical use of nanomaterials, to nanoelectronics biosensors, and even possible future applications of molecular nanotechnology. The speculative field of molecular nanotechnology believes that cell repair machines could revolutionise medicine. Nanotechnology's health implications can be split into two aspects: (a) the potential for nanotechnological innovations to have medical applications to cure disease and (b) the potential health hazards posed by exposure to nanomaterials. ${ }^{11}$

There exist a plethora of different kinds of nanostructures based on the variety of forming components like gold, iron oxide, carbon, dielectric elements, molecular, liposomal and shapes (e.g., spheres, rods, triangles, cubes), along with solid nanoparticles, nanoshells (within inner and outer cores), nanocages, nanowire, nanotubes, branched dendrimers, and polymeric and organic lipid nanoparticles. Inorganic nanoparticles have the most distinctive electronic, magnetic, optical, photothermal, or catalytic properties at the nanoscale. At present, plasmonic gold nanoparticles are notably encouraging, amongst the collection of nanostructure types, due to their uncomplicated structure, multifunctional quality, facile surface chemistry bio-distribution properties, and somewhat reduced toxicity. ${ }^{12-14}$

Based on nanotechnology, nanocarriers have been synthesized from organic and inorganic materials to enhance the performance of medicines, reduce systemic side effects and enhance therapeutic efficiency. A drug may be adsorbed or attached to or encapsulated in the nanocarriers. The targeting of molecules or drugs can be passive or active; the first exploits the characteristic features of target tissue biology, whereas, in active approaches, nanocarriers are conjugated with molecules able to bind overexpressed antigens or receptors present on the target cell surface. The molecules bound on nanocarriers 
can be proteins (mainly antibodies and their fragments), nucleic acids (aptamers), or other receptor ligands (peptides, vitamins, and carbohydrates). Variations caused in physical stimuli like temperature, $\mathrm{pH}$ etc. can be useful in active targeting of the cells. ${ }^{15}$ In the targeted diseased tissue, the drug is released in a controlled manner through changes in the physiological environment, such as temperature, $\mathrm{pH}$, osmolality, or via some enzymatic activity.

Nanocarriers exploited in medical applications: (a) are made from a biocompatible, well-characterized, and easily functionalized material; (b) exhibit high differential uptake efficiency in ill cells compared to healthy cells; (c) is either soluble or colloidal in aqueous conditions to increase their effectiveness; (d) have an extended circulating half-life, a low rate of aggregation, and a long shelf life. ${ }^{16}$ The main nanocarrier systems are liposomes, micelles, niosomes, nanoparticles, dendrimers and nanofibers. Liposomes (80-300 $\mathrm{nm}$ size range) were the first drug carriers investigated. ${ }^{17}$ They are artificially prepared vesicles composed of monolamellar or multilamellar bilayers of phospholipids and steroids (e.g., cholesterol). They can transport both hydrophilic and hydrophobic molecules via encapsulation in their aqueous core or their hydrophobic membrane respectively. ${ }^{18}$ Micelles (10-100 nm size range) are spherical self-assemblies of amphiphilicblock copolymers in an aqueous environment, consisting of a poly(ethylene glycol) (PEG) hydrophilic corona and a hydrophobic core, composed of polymers like poly( $\varepsilon$-caprolactone) (PLC) and poly(D, Llactic acid) (PLA) allowing solubilization of lipophilic drugs. ${ }^{19}$ Niosomes, structurally similar to liposomes, are non-ionic surfactant vesicles having a multilamellar or unilamellar bilayer structure. Niosomes are formed by hydration of non-ionic surfactant dried films and can entrap both hydrophilic and lipophilic drugs in the aqueous layer and vesicular membrane, respectively. ${ }^{20}$

The nanoparticles include (1) carbon-based nanoparticles, including fullerenes and single (SWCNTs)and multi(MWCNTs)-walled carbon nanotubes; (2) metal-based nanoparticles, such as gold colloids, nanoshells, nanorods, and superparamagnetic iron oxide nanoparticles (spherical nanocrystals with $\mathrm{Fe} 2+$ and $\mathrm{Fe} 3+$ cores); and (3), semiconductor-based nanoparticles such as quantum dots (QDs colloidal fluorescent semiconductor nanocrystals). ${ }^{21}$ Dendrimers are artificial macromolecules with tree-like structures in which the atoms are arranged in many branches and subbranches radiating out from a cen- tral core. Their architecture offers unique advantages since they can transport molecules both in their internal cavities or attached to their branches; moreover, the branches can be exploited to attach functional groups improving the precise targeting. ${ }^{22}$ Nano fibres are ultrafine polymer fibres with diameters ranging from tens of nanometres to 1 micron obtained by electrospinning a polymer solution. As a fibrous scaffold, nanofibers can entrap drugs with high loading capacity and high encapsulation efficiency because of their low weight and inherent high surface-to-volume ratio. ${ }^{23}$

The question arises why to use nanotechnology? Nanotechnology can be helpful in developing various devices for diagnosis and treatment in medical and dental field. As nanoparticle have a size (1-200 $\mathrm{nm})$ similar to biologic molecules and various structures found inside living cells, they can be used for imaging and manipulation at the molecular level. Also the surface chemistry of the nanoparticles can be controlled; hence they can be used in conjugation with various ligands for interaction at the cellular and molecular level. ${ }^{24}$

\section{THE ROLE OF NANOTECHNOLOGY IN CANCER MANAGEMENT}

Nanotechnology appears to be in a position to provide device efficient of 1 ) sensitive and specific anatomic, molecular, and biologic imaging; 2) selective treatment of tumours; and 3) comparatively reduced toxicity. There is a strong possibility that the physical characteristics of most of the nanostructures can result in a significant enhancement in the current quality of patient care. The assessments of tumour's stage, invasive treatments, and post-treatment monitoring with physical examination and routine imaging are recommended for patients with head and neck cancer for 5 years and the chief modalities for diagnosis and follow-up head and neck cancer patients are MRI, CT, ultrasonography, and positron emission tomography (PET). These techniques have limited resolution and cannot detect microscopic or molecular changes. Further, interpretation of findings can be complicated by difficult anatomy, oedema or inflammation, scarring from prior treatment, and loss of detail because of patient movement or dental implants. False-positive findings can occur on PET imaging because of inflammatory or infectious processes. Furthermore, the imaging techniques are quite poor for the diagnosis of small surface lesions since precise detection demands tissue diagnosis with biopsy or needle aspiration whereas it is diffi- 
cult to diagnose an intraoperative tumour at the surgical margins. However, advancement in the sensitive and specific non-invasive molecular testing for staging, screening, and intraoperative diagnosis will lead to the betterment of patient comfort.

Currently available therapies for head and neck cancer suffer significant limitations. In the head and neck, surgical resection is limited by several adjacent important structures such as the carotid artery, eye, and brain. Then adjuvant therapies are needed for the treatment the residual parts of the tumor left behind near these vital structures. Due to high toxicity, radiation therapy has a limited use and high failure rate especially for the advanced tumours and chemotherapy only has a supportive role. Nanotechnology as a tool can not only open a new arena for diagnosis part, but can be help in development of novel therapeutic devices like gene delivery vectors, radiation enhancers, photo and magneto-thermal probes etc. $^{25}$

\section{ROLE OF GOLD LABELLED NANOCONJU- GATES IN CANCER RESEARCH}

During the past decade, gold nanoparticles (AuNPs) have been the focus of numerous experimental and clinical studies. ${ }^{25}$ Gold-based nanomaterials have been used to design and improve novel drug delivery systems which could represent a significant future improvement of the existing cancer chemotherapy. Also, many researchers consider Au NPs to be a valuable addition to the present diagnostic, imaging, and bioassay techniques. The surface of $\mathrm{Au} \mathrm{NPs,}$ due to its unique properties can easily be modified with ligands containing various functional groups. Resulting gold nanoconjugates based on the type of surface functionalization include citrates, amines, nucleic acids, peptides, antibody-labelled conjugates, and lipid ligand associated conjugates. Surface functionalization of $\mathrm{Au}$ NPs enables them to have an adequate biodistribution in various living tissues and organs as well as to specifically target and accumulate in cells with certain membrane receptors. $^{26}$

1. Role in image studying: Antibody-labelled gold nanoconjugates have so far been used in developing a diagnostic imaging assay by which a physician would be able to visualize cancer cells and distinguish them from the normal, unchanged tissue. Most of the imaging studies have been focused on designing a conjugate that would be capable of selectively binding to a certain growth factor receptor or other membrane molecules specific for the cancer cells, making it visible and detectable. ${ }^{26}$ It was found that the anti-EGFR antibody conjugated nanoparticles were able to specifically attach to oral cancer cells (with 6 times greater affinity than to non-malignant cells), changing their spectroscopic and surface plasmon resonance characteristics. Antibody-labelled gold nanoconjugates have also been applied in photoacoustic imaging.

Photoacoustic imaging represents a novel, noninvasive method that is based on the so-called photoacoustic effect, a physical phenomenon in which the absorbed energy from the light is converted to kinetic energy resulting in sound (wave) formation. ${ }^{23}$ It is thought that using this method, gold nanorods conjugated with HER2 and CXCR4 monoclonal antibodies, could be useful for the estimation and measurement of oncogene expression in cancer cells. ${ }^{27}$ However, the usage has certain limitations. It is often hard to design a conjugate that is $100 \%$ specific for the cancer cell, since many normal calls may also possess the molecule that is being targeted (although in smaller concentrations).

2. Role in photothermal therapy: Photothermal therapy is a new cancer treatment approach in which electromagnetic infrared radiation is used to selectively target and destroy abnormal tissue. The photothermal effect takes place when a specific compound called a photosensitizer, after being excited with light, emits thermal energy. Nanoparticles as photosensitizers can absorb and scatter light strongly at a characteristic wavelength which is called plasmon resonance. ${ }^{28}$ It is known that nanoparticles with certain geometrical shapes, such as rods and shells, can have their Plasmon resonance tuned to the nearinfrared (NIR) region of the spectrum, which is of great clinical importance because light at this wavelength can penetrate deep into the tissues.

Anti-EGFR antibody-conjugated gold nanoparticles were successfully used for photothermal destruction of cancer cells. Due to the selective antibody binding to EGFR overexpressing cells, laser power thresholds for cancer cells were significantly lower than the thresholds for normal tissue. This and other studies concerning Anti-EGFR Au nanoconjugates set the basis for further research in in -vivo conditions. ${ }^{11}$ One of the first studies investigating the photothermal ablation properties of anti-EGFR Au NPs in vivo was carried out in mice, by injecting viable tumour cells that eventually developed detectable tumour tissue. $^{29}$

Anti-HER2 $\mathrm{Au}$ NPs is another promising candidate for efficient photothermal therapy design. Since 
HER2 is a cell membrane surface-bound receptor tyrosine kinase and is a clinically important breast cancer biomarker, some authors assume that the nanoconjugates can exhibit sufficient absorption to enable effective photothermal ablation of breast cancer tissue. $^{30}$

\section{NANOMATERIALS AND TUMOUR VACCINE}

Use of vaccine as an antineoplastic therapy against tumour cells, cell lysates and antigens are increasingly being considered to activate the immune system against tumour cells. ${ }^{31}$ Derived from autologous and allogenic tumour cells, these vaccines can not only stimulate specific immune responses but can also help in overcoming immune suppression caused by the tumour products. ${ }^{32}$

Ideally this type of vaccine should be easy to formulate, manufacture, transport and administer and inexpensive. It should also be stable over a range of temperature and should be able to provide lifelong immunity. ${ }^{33}$ Nanostructure is composed of the basic particle of the artificial or natural materials. Due to the special thermodynamic, magnetic, optical and quantum properties; tumour vaccines prepared form the nanomaterials have shown promising results for prevention and treatment of cancer. ${ }^{34}$

Combination of nanomaterials with Tumour antigens has increased the permeability, biocompatibility and targeting properties of a tumour vaccine. This can also be attributed to the fact that nanomaterials are antigenic, hence can stimulate strong immune response in the body. ${ }^{35}$ These properties make them a suitable choice to be used increasingly in the field of tumour vaccine.

a. Carbon nanotubes: Carbon nanotubes that are formed by aggregation of single carbon atoms under specific settings have been used as carriers for a dendritic cell tumour vaccine. ${ }^{36}$ A dendritic cell tumour vaccine was developed in -vitro, by loading different amounts of tumour protein antigens against dendritic cells into CNT that stimulate the immune system to produce more $\mathrm{T}$ cells, to destroy the tumour. The binding of CNT and tumour proteins occurs with a covalent bond or by the formation of complexes between CNT and tumour proteins. The CNT stimulates phagocytosis of dendritic cells in the tumour tissue, such that more antigens to the dendritic cell are formed, significantly enhancing the immunogenicity of proteins in the tumour ${ }^{37}$ which eventually enhance the efficacy of lymphocytes to attack and destroy the tumour. ${ }^{38}$ Besides, the direct stimulation of CNT-tumour protein complex by the lymphocytes themselves further boosts the lymphocyte's efficacy of destroying tumour cells. Strong antibody response was reported during the immunization of a BALB/c mice with a foot and mouth disease virus polypeptide attached to CNT. Whereas enhanced immunotherapy was observed with the use of a multiwalled CNT conjugated with tumour lysate protein (tumour cell vaccine) in a mouse model of H22 liver cancer. ${ }^{39}$

Selective permeability of the cell membrane to most of the biological macromolecules, including proteins, restricts the use of tumour vaccines. ${ }^{29}$ The adsorption of DNA molecules, nucleic acids, proteins, and other biological molecules onto the outer wall of CNT occurs due to electrostatic and hydrophobic phenomenon. ${ }^{40}$ While their biological activity is retained and maximized by indistinct interactions with CNT. Thereupon CNT enters the cells by utilization of its passive energy and the receptormediated endocytosis. ${ }^{41}$ Additional assumption describes the diffusion of CNT into cells as an active process which ensues at the phospholipid bilayer of the cell membrane. Tumour-specific antigens laden CNT are stable and can be transported into various cells, tissues, and organs, where the tumour-specific antigens accomplish their biological function. There is medical evidence of single-walled CNT being utilized as antigen carriers, through which Wilms' tumour antigen was solubilized onto single-walled CNT scaffolds followed by immediate internalization within antigen-presenting cells for recognition by $\mathrm{T}$ cells. This proves that $\mathrm{CNT}$ are ideal carriers for tumour vaccines. ${ }^{42}$

b. Nanoemulsions: An emulsion is called nanoemulsion, when diameter of the droplet of emulsion is measured in nanoscale. When two immiscible liquids coexist in a thermodynamically stable isotopic appearance in a translucent or transparent dispersion system, a nanoemulsion is created. It can be a) oil-in-water (o/w), b) water-in-oil (w/o), and c) bicontinuous types. ${ }^{43}$ Because of their strong affinity for lymphatic system, they have an advantage as carrier for tumor vaccine. Hence, they can gather in the regional lymph nodes and can stimulate lymphocytes to proliferate. In case of w/o nanoemulsions, they can increase the bio availability if a tumour antigen by ensuring its sustained release. $\mathrm{W} / \mathrm{O}$ nanoemulsions have the outer surface of oil reservoir, which acts as a partition and protects the contents from the destructive effects of enzymes. ${ }^{44}$ W/o nanoemulsions are being researched for vaccines for AIDS and immunotherapy for cancer. 
However, due to lack of standardised methods and guidelines, preparation of nanoemulsions is quite difficult. $^{45}$

c. Chitosan nanoparticles: Chitosan is a biopolymer which is produced by deacetylation of chitin. It also exists in nature in natural form as a major component of the outer shell of animals with exoskeletons. It is non-toxic, biodegradable and biocompatible in nature. Chitosan has excellent biodegradability, biocompatibility, and biosecurity, and overall non-toxic characteristics. ${ }^{46,47}$ These particles have high stability and protein packing efficiency and can be easily stored and transported as lyophilized powder. $^{48}$

Nanochitosan particles due to their strong stimulatory effect on $\mathrm{T}$ and $\mathrm{B}$ lymphocytes and cellular and humoral immune system, have shown great potential. This can attribute to their ability to accumulate in increasing quantity in macrophages and polymorphonuclear cells; thereby causing their activation. ${ }^{49,50}$ This makes them a great carrier for cancer gene vaccines.

Limitations of the use of Nanotechnology: Though use of nanotechnology has shown promising results there are a few limitations associated with the use First of all, biocompatibility of the material is a major issue. Also the availability of these particles and technologies using these particles at an affordable and basic level is another major concern. There is another major limitation of this technology i.e. since it is a newer field, ethical and legal aspects need to be dealt with before using these particles for research and treatment. ${ }^{51,52}$

In Conclusion: Immuno-targeted gold nanomaterials represent a novel, efficient and relatively affordable addition to the present knowledge regarding cancer imaging and treatment. However, many issues remain unresolved. Firstly, many of the studies previously mentioned failed to address the potential toxicity of gold nanomaterials in a living organism. There is insufficient data regarding both nephrotoxicity and hepatotoxicity, particularly having in mind that standard rules concerning bio-distribution and membrane transport do not always apply to nanoscale objects. Immunotoxicity and immune response modulation of certain nanomaterials must also be taken into account when considering their clinical value.

Secondly, there is insufficient evidence to draw a definite conclusion on the effectiveness and potential side effects of antibody-Au NPs-based thermotherapy. Although serious research efforts are being made towards this goal, still many questions remain unanswered. It is known that the certain cancer molecular markers targeted by antibodies are also expressed on normal non-malignant cells, and therefore it is reasonable to assume that normal tissue could be also significantly affected by thermotherapy if proper precautions are not taken.

Future research will have to focus on designing new strategies to make various therapies like thermotherapy etc. more specific to cancer tissue, as well as to precisely define the optimal temperature and nanoparticle concentrations that would minimize the negative effects on healthy tissue. To achieve this goal, a multidisciplinary approach is needed, including the cooperation of biophysics experts, molecular biologists and medical practitioners. Only through a multidisciplinary approach, a definitive road to treatment of oral cancers can be achieved.

Ethics Committee Approval: Our study was a review article. No ethics committee permission is required.

Conflict of Interest: No conflict of interest was declared by the authors.

Author Contributions: Concept - AJ; Supervision - AS; Materials -AJ, AS; Data Collection and/or Processing - AJ, AS; Analysis and/ or Interpretation - AJ, AS; Writing - AJ, AS.

Peer-review: It is an article invited by the editor.

\section{REFERENCES}

1. Keshavarzi M, Darijani M, Momeni F, et al. Molecular imaging and oral cancer diagnosis and therapy. J Cell Biochem. 2017;118(10):3055 -3060. doi:10.1002/jcb.26042

2. Silva GA. Introduction to nanotechnology and its applications to medicine. Surg Neurol. 2004;61:216-20.

3. Myers EN, Suen JY. Perspectives in head and neck cancer. In cancer of the head and neck. Edited by Myers EN, Suen JY, Myers JN, Hanna EY. Philadelphia, PA: Saunders; 2003:1-5.

4. Bonner JA, Harari PM, Giralt J, et al. Radiotherapy plus cetuximab for squamous-cell carcinoma of the head and neck. N Engl J Med. 2006;354:567-578.

5. Chen XJ, Zhang XQ, Liu Q, Zhang J, Zhou G. Nanotechnology: a promising method for oral cancer detection and diagnosis. J Nanobiotechnology. 2018;16(1):52.

6. American Cancer Society: Cancer Facts and Figures, 2009. https://www.cancer.org/research/ 
cancer-facts-statistics/all-cancer-facts-figures/ cancer-facts-figures-2009.html. Accessed May $10,2020$.

7. Lentsch EJ, Myers JN. Pathogenesis and progression of squamous cell carcinoma of the head and neck. In Cancer of the Head and Neck. Edited by Myers EN, Suen JY, Myers JN, Hanna EY. Philadelphia, PA: Saunders; 2003:5-28.

8. Lumerman H1, Freedman P, Kerpel S. Oral epithelial dysplasia and the development of invasive squamous cell carcinoma. Oral Surg Oral Med Oral Pathol Oral Radiol Endod. 1995;79(3):3219.

9. Hall CS, Scott MJ, Lanza GM, Miller JG, Wickline SA. The extracellular matrix is an important source of ultrasound backscatter from myocardium. J Acoust Soc Am. 2000;107(1):612-9.

10. Sokolov K, Follen M, Aaron J, et al. Real-time vital optical imaging of precancer using antiepidermal growth factor receptor antibodies conjugated to gold nanoparticles. Cancer Res. 2003;63(9):1999-2004.

11. Ravi Kumar Reddy J, Guna Sagar E, Bala Chandra Prathap S, Ramesh Kumar B, Madhusudhana Chetty C. Nanomedicine and drug delivery. Revolution in health system. Journal of Global Trends in Pharmaceutical Sciences. 2011;2:21-30.

12. Bayda S, Hadla M, Palazzolo S, et al. Inorganic Nanoparticles for Cancer Therapy: A Transition from Lab to Clinic. Curr Med Chem. 2018;25 (34):4269-4303. doi:10.2174/0929867325666171229141156

13. Huang X, Jain PK, El-Sayed IH, El-Sayed MA. Gold nanoparticles: interesting optical properties and recent applications in cancer diagnostics and therapy. Nanomed. 2007;2:681-693.

14. Bao G, Mitragotri S, Tong S. Multifunctional nanoparticles for drug delivery and molecular imaging. Annu Rev Biomed Eng. 2013;15:253282 . doi:10.1146/annurev-bioeng-071812152409

15. Nevozhay D, Kanska U, Budzynska R, Boratyński J. Current status of research on conjugates and related drug delivery systems in the treatment of cancer and other diseases. Postepy Hig. Med. Dosw. 2007;61:350-360.

16. Ai J, Biazar E, Jafarpour M, et al. Nanotoxicology and nanoparticle safety in biomedical designs. Int. J. Nanomedicine 2011;6:1117-1127.

17. Duncan, R. The dawning era of polymer therapeutics. Nat. Rev. Drug Discov. 2003;2:347-360.
18. Torchilin, V.P. Recent advances with liposomes as pharmaceutical carriers. Nat. Rev. Drug Discov. 2005;4:145-160.

19. Blanco E, Kessinger CW, Sumer BD, Gao J. Multifunctional micellar nanomedicine for cancer therapy. Exp. Biol. Med. 2009;234:123-131.

20. Sankhyan A, Pawar P. Recent trends in noisome as vesicular drug delivery system. J. Appl. Pharm. Sci. 2012;2:20-32.

21. Sanvicens N, Marco MP. Multifunctional nanoparticles-Properties and prospects for their use in human medicine. Trends Biotechnol. 2008;26:425-433.

22. Svenson S, Tomalia DA. Dendrimers in biomedical applications-reflections on the field. Adv. Drug Deliv. Rev. 2005;57:2106-2129.

23. Wang H, Xing D, Xiang L. Photoacoustic imaging using an ultrasonic Fresnel zone plate transducer. J. Phys. D: Appl. Phys. 2008;41(9). doi: https://doi.org/10.1088/0022-3727/41/9/095111

24. Whitesides GM. The "right" size in nanobiotechnology. Nat Biotechnol. 2003;21:1161-1165.

25. Bac LH, Kim JS, Kim JC. Size, optical and stability properties of gold nanoparticles synthesized by electrical explosion of wire in different aqueous media. Rev. Adv. Mater. Sci. 2011;28:117121.

26. Guo J, Rahme K, He Y, Li LL, Holmes JD, O'Driscoll CM. Gold nanoparticles enlighten the future of cancer theranostics. Int J Nanomedicine. 2017;12:6131-6152. doi:10.2147/ IJN.S140772

27.Li PC, Wei CW, Liao CK, et al. Photoacoustic imaging of multiple targets using gold nanorods. IEEE Trans Ultrason Ferroelectr Freq Control. 2007;54(8):1642-7.

28. Krishnan S, Diagaradjane P, Cho SH. Nanoparticle-mediated thermal therapy: evolving strategies for prostate cancer therapy. Int J Hyperthermia. 2010;26(8):775-89.

29. Melancon MP, Lu W, Yang Z, et al. In vitro and in vivo targeting of hollow gold nanoshells directed at epidermal growth factor receptor for photothermal ablation therapy. Mol Cancer Ther. 2008;7(6):1730-9.

30. Loo C, Lowery A, Halas N, West J, Drezek R. Immunotargeted nanoshells for integrated cancer imaging and therapy. Nano Lett. 2005;5(4):70911.

31. Rosenberg SA, Yang JC, Restifo NP. Cancer immunotherapy: moving beyond current vaccines. Nat Med. 2004;10(9):909-915. 
32. Pistoia V, Morandi F, Pezzolo A, Raffaghello L, Prigione I. MYCN: from oncoprotein to tumorassociated antigen. Front Oncol.2012;2:174.

33. Nasir A. Nanotechnology in vaccine development: a step forward. J Invest Dermatol. 2009;129(5):1055-1059.

34. Viswambari Devi R, Doble M, Verma RS. Nanomaterials for early detection of cancer biomarker with special emphasis on gold nanoparticles in immunoassays/sensors. Biosens Bioelectron. 2015;68:688-698. doi:10.1016/ j.bios.2015.01.066

35. Malmo J, Sandvig A, Vårum KM, Strand SP. Nanoparticle mediated P-glycoprotein silencing for improved drug delivery across the bloodbrain barrier: a siRNA-chitosan approach. PLoS One. 2013;8(1):e54182.

36. Terrones M, Terrones H. The carbon nanocosmos: novel materials for the twenty-first century. Philos Transact A Math Phys Eng Sci. 2003;361 (1813):2789-2806.

37. Shen H, Ackerman AL, Cody V, et al. Enhanced and prolonged cross-presentation following endosomal escape of exogenous antigens encapsulated in biodegradable nanoparticles. Immunology. 2006;117(1):78-88.

38. Salcedo M, Bercovici N, Taylor R, et al. Vaccination of melanoma patients using dendritic cells loaded with an allogeneic tumor cell lysate. Cancer Immunol Immunother. 2006;55(7):819-829.

39. Pantarotto D, Partidos CD, Hoebeke J, et al. Immunization with peptide-functionalized carbon nanotubes enhances virus-specific neutralizing antibody responses. Chem Biol. 2003;10(10):961-966.

40. Madani SY, Tan A, Dwek M, Seifalian AM. Functionalization of single-walled carbon nanotubes and their binding to cancer cells. Int $\mathrm{J}$ Nanomedicine. 2012;7:905-914.

41. Kam NW, Liu Z, Dai H. Carbon nanotubes as intracellular transporters for proteins and DNA: an investigation of the uptake mechanism and pathway. Angew Chem Int Ed Engl. 2006;45 (4):577-581.

42. Klumpp C, Kostarelos K, Prato M, Bianco A. Functionalized carbon nanotubes as emerging nanovectors for the delivery of therapeutics. Biochim Biophys Acta. 2006;1758(3):404-412.

43. Sakaeda T, Hirano K. O/W lipid emulsions for parenteral drug delivery. II. Effect of composition on pharmacokinetics of incorporated drug. J Drug Target. 1995;3(3):221-230.

44. Ge W, Hu PZ, Huang Y, et al. The antitumor im- mune responses induced by nanoemulsionencapsulated MAGE1-HSP70/SEA complex protein vaccine following different administration routes. Oncol Rep. 2009;22(4):915-920.

45. Ge W, Sui YF, Wu DC, et al. MAGE-1/heat shock protein 70/MAGE-3 fusion protein vaccine in nanoemulsion enhances cellular and humoral immune responses to MAGE-1 or MAGE-3 in vivo. Cancer Immunol Immunother. 2006;55(7):841-849.

46. Illum L, Jabbal-Gill I, Hinchcliffe M, Fisher AN, Davis SS. Chitosan as a novel nasal delivery system for vaccines. Adv Drug Deliv Rev. 2001;51(13):81-96.

47. Shi SF, Jia JF, Guo XK, et al. Biocompatibility of chitosan-coated iron oxide nanoparticles with osteoblast cells. Int J Nanomedicine. 2012;7:55935602 .

48. Chen F, Shi Z, Neoh KG, Kang ET. Antioxidant and antibacterial activities of eugenol and carvacrol -grafted chitosan nanoparticles. Biotechnol Bioeng. 2009;104(1):30-39.

49. Sayin B, Somavarapu S, Li XW, et al. Mono-Ncarboxymethyl chitosan (MCC) and N-trimethyl chitosan (TMC) nanoparticles for non-invasive vaccine delivery. Int J Pharm. 2008;363(1-2):139148.

50. Seferian PG, Martinez ML. Immune stimulating activity of two new chitosan containing adjuvant formulations. Vaccine. 2009;19(6):661-668.

51. Alok A, Panat S, Aggarwal A, Upadhyay N, Agarwal N, Kishore M. Nanotechnology: A boon in oral cancer diagnosis and therapeutics. SRM J Res Dent Sci. 2013;4:154-60.

52. Revia RA, Stephen ZR, Zhang M. Theranostic Nanoparticles for RNA-Based Cancer Treatment. Acc Chem Res. 2019;52(6):1496-1506. doi:10.1021/ acs.accounts.9b00101 